DOI: $10.15290 /$ bsl.2020.16.03

Katarzyna Szalewska

Wydział Filologiczny

Uniwersytet Gdański

e-mail: k.szalewska@ug.edu.pl

ORCID: 0000-0003-2121-9864

\title{
Dzielnica jako miejsca afektywne - Cwaniary Sylwii Chutnik i Królowa Salwatora Emmy Popik
}

Analizując problem przestrzeni publicznej jako formy reprezentacji lokalnych społeczności, Mariusz Czepczyński pisze:

Podsystem urbanistyczny zmienia się z reguły wolniej niż społeczny, „zostaje w tyle", odzwierciedlając potrzeby społeczne formułowane wczoraj [...]. Żyjemy więc zazwyczaj we "wczorajszych przestrzeniach", reprezentujących „wczorajsze" potrzeby i „wczorajszych" aktorów. Przestrzeń miejska, a zwłaszcza centra miast są specyficzną przestrzenią społeczną i urbanistyczną, którą można określić jako przestrzeń dialogowaną, tworzoną przez nieustanną interakcję między formami, funkcjami, ich znaczeniami oraz odbiorcami. [...]. Przestrzeń miast jest szczególnego rodzaju symbolem, częścią kultury zarazem i najbardziej chyba widocznym jej transmiterem, wyrażającym hierarchie wartości, sposoby myślenia i doświadczenia dominującej grupy społecznej ${ }^{1}$.

Uznanie miasta za przestrzeń dialogu, miejsce negocjowania znaczeń między odbiorcami pozwala widzieć w polis swoisty papierek lakmusowy społecznych przemian, ewoluujących pragnień i potrzeb mieszkańców. Miasto jako "transmiter" kultury okazuje się również pewnego rodzaju ekranem, na który rzutowane są lokalne konflikty, ale też przestrzeń publiczną widzieć można jako scenę ich rozgrywania. W tym sensie okazuje się ona

1 M. Czepczyński, Przestrzeń publiczna jako forma reprezentacji społeczności lokalnych. Między hibernacja a animacja centrów małych miast woj. pomorskiego, „Studia KZPK” 2012, nr 144, s. 8. 
sferą zagospodarowywaną $\mathrm{w}$ sensie nie tylko symbolicznym (jako że wyraża społeczne „hierarchie wartości, sposoby myślenia i doświadczenia”), ale także emocjonalnym (emocje stanowią bowiem nieodłączny element konfliktu).

Miasto jako miejsce afektywne ${ }^{2}$ ilustruje Sylwia Chutnik w powieści Cwaniary. Nie chcąc zbyt wiele miejsca poświęcać wielokrotnie już podejmowanym przez interpretatorów ${ }^{3}$ tego tekstu kwestiom "prawa do miasta" i oddolnych, iście rewolucyjnych, działań mieszkańców przeciw deweloperom, starczy tylko przywołać krótki zarys fabuły. Streścić ją można w formule awanturniczej historii o krzywdzie i zemście. Grupa młodych kobiet - tytułowych „cwaniar" - nie tylko wymierza sprawiedliwość społeczną na ulicy, stając się obrończyniami sprawiedliwości, mierzy się z problemami osobistymi, ale również przygotowuje miejską akcję przeciw burzącemu stare budynki biznesmenowi. Bohaterki Chutnik wypełniają emocje - od miłości po gniew, od ekstazy po rozpacz - a ich katalizatorem staje się Warszawa. Cwaniary nie tylko ingerują $w$ przestrzeń publiczną, ale też czynią ją ekranem własnych afektów. Miasto przeistacza się u Chutnik w scenę rozgrywania emocji bohaterek, a tak silna psychizacja przestrzeni wiąże się również z połączeniem kwestii tożsamości podmiotu z zagadnieniem miejsca, jakie zamieszkuje i udomawia ${ }^{4}$.

Rewersem strategii pisarskiej Chutnik można by uznać wydaną w 2019 roku powieść Emmy Popik Królowa Salwatora. Choć także tu mamy do czynienia z grupą bohaterek, które z Petrą - "kierowniczką" dzielnicowego klubu na czele - walczą z nieuczciwymi deweloperami, to jednak w stylistyce i kreacji postaci Popik sytuuje się na przeciwległym biegunie wobec poetyki wybranej przez autorkę Cwaniar. Chutnik tworzy swoją powieść, sięgając do formuł popkulturowych, komiksowych i filmowych, do literatury łotrzykowskiej i tradycji "ludu” miejskiego. Królowa Salwatora z kolei jest sentymentalną opowieścią o walce dobra ze złem, społeczników i zmarginalizo-

\footnotetext{
2 czyli takie, „,które w szczególny sposób wyzwala emocje, zaangażowania, postawy, mające charakter kulturowy, nieindywidualny" [M. Barbaruk, Sensy btądzenia. La Mancha i jej peryferie, Kraków-Nowy Sącz 2018, s. 8].

3 Zob. np. A. Hołubowicz, Miasto jako przestrzeń zagrożona - refleksje na podstawie powieści "Cwaniary" Sylwii Chutnik, „Jednak Książki. Gdańskie Czasopismo Humanistyczne” 2014, nr 1; D. Kozicka, Sylwia Chutnik, czyli kobieta w mieście, "Śląskie Studia Polonistyczne" 2015, nr 1; E. Sidoruk, "Okolica znana, oswojona”. Warszawa w "Cwaniarach” Sylwii Chutnik, „Białostockie Studia Literaturoznawcze" 2018, nr 13.

4 Nie ma tu miejsca, by rozwijać tę znaną kwestię swojskości i zadomowienia jako sytuacji egzystencjalnych - zob. H. Buczyńska-Garewicz, Miejsca, strony, okolice. Przyczynek do fenomenologii przestrzeni, Kraków 2006.
} 
wanych biedaków z przebiegłymi deweloperami, ambitnymi karierowiczami i łowcami poniemieckich skarbów. Jeśli Chutnik realizuje Frye'owski model tragedii (choć okraszonej sporą dawką humoru i groteski), to Popik kończy swoją powieść komediową sceną powszechnej zgody i prognozy przyszłej szczęśliwości. Różnice w konstruowaniu postaci i fabuły, ale także w stylistyce tekstu uwidacznia zestawienie opisu Petry z Królowej Salwatora z fragmentem Cwaniar.

Gdy znalazła się na ulicy, wyprostowała się i rozejrzała wokoło. Serce jej napełniało się czułością, gdy patrzyła na domy i stare bruki, po których przeszło już tyle pokoleń. Podniosła głowę szybkim szarpnięciem. Nie podda się, to tylko jedno niepowodzenie. Nagle wpadła na wyjście z sytuacji. Jeden jest sposób: wyprzedzić go, napisać projekt, zaangażować ludzi, zacząć konkretne działania. [...] Jakże kochała to miejsce, była zdolna do wszelkich poświęceń, by je ratować [wyróż. - K.S.] .

Już ten krótki passus pozwala widzieć powieść Popik jako manifest miłości do miasta. Słownictwa opisującego emocjonalny stan bohaterek jest zresztą w tym utworze dużo, co wynika zarówno z sentymentalnej konwencji całości, jak i z konstruowania motywacji działań postaci. Bohaterki, w tym przede wszystkim Petra, działają, gdyż pcha je ku temu uczucie do przestrzeni, poczucie odpowiedzialności i przynależności. Środkiem do walki stają się natomiast legalistyczne działania („napisać projekt, zaangażować ludzi, zacząć konkretne działania") - Królowa Salwatora stanowi pochwałę oddolnych, obywatelskich akcji mieszkańców, aktywizacji i rewitalizacji biednych dzielnic Gdańska (takich jak właśnie opisana w powieści Biskupia Górka). W tej perspektywie cała fabuła jawi się jako nieco schematyczna ilustracja hasła "prawa do miasta" i oddolnych inicjatyw proobywatelskich.

Powyższy fragment Królowej Salwatora skontrastować można z cytatem z książki Chutnik: „Ale dziewczyny gadać, komentować chciały, a czemu nie. Oburzone, wściekłe wręcz, zaczęły dopytywać się o szczegóły. Kiedy spalenie, kiedy wysiedlenie i, przede wszystkim, imię i nazwisko kamienicznika złego" ${ }^{\prime}$ [wyróż. - K.S.]. O ile więc Popik proponuje legalne działania obejmujące pisanie projektów i zdobywanie funduszy, o tyle u Chutnik bohaterki widzą możliwość zmiany $w$ anarchii i rewolucji. Są to nie tylko dwa modele miejskiego aktywizmu (spójne na poziomie tekstowym z przyjętą konwencją konstrukcji bohaterów i języka opisu), lecz również dwie formy kanalizowania afektów mieszkańców miasta - poprzez wspólne świętowanie

\footnotetext{
5 E. Popik, Królowa Salwatora, Gdańsk 2019, s. 157.

6 S. Chutnik, Cwaniary, il. M. Zabłocka, Warszawa 2012, s. 96.
} 
(jak w końcowych scenach Królowej Salwatora) i solidarność oraz poprzez niezgodę i gniew. Mimo tych kontrastów obie powieści są świadectwami silnego przywiązania do miasta, miłości do warszawskiego Mokotowa (u Chutnik) i gdańskiej Biskupiej Górki (u Popik), ale też przykładami takiej konstrukcji literackiej przestrzeni, w której staje się ona „punktem odniesienia i celem narracyjnych zabiegów, a w konsekwencji - przestrzenią ideologicznych rozgrywek"7. Tym, co łączy najsilniej Cwaniary i Królowa Salwatora, są więc emocje projektowane na miasto i przeobrażenia przestrzeni publicznej, które powieści te dokumentują.

Podstawową emocją odczuwaną i werbalizowaną przez bohaterki obu książek jest miłość do miasta. W Królowej Salwatora czytamy:

Każdy dom, cegły, kamienie, widoki i zakręty, światło na szybach wzbudzały w niej miłość tak wielką, że nie mogła żyć poza tym miejscem. Oddałaby wszystko, wszystkie dni i działania, aby ocalić dzielnicę. Wewnątrz, w swoim sercu i psychice czuła wielkie emocje, gnały w różne strony i rozdzierały ją wewnętrznie. Nie pokazywała niczego po sobie, była jak z kamienia: odpowiadała grzecznie i uprzejmie się uśmiechała, lecz zaciskała zęby i wbijała paznokcie we wnętrza dłoni [wyróż. - K.S.] ${ }^{8}$.

Miłość do miasta staje się motorem napędowym działań bohaterek, a tym samym - fabuły obu powieści. Namiętność ta złączona jest równie silnie z gniewem - przetworzenie znanego schematu romansowego, w którym bohater musi $\mathrm{w}$ imię miłości ratować swą heroinę $\mathrm{z}$ rąk agresora, opiera się na utworzeniu „miłosnego trójkąta”: mieszkaniec (a właściwie - co znamienne i do czego wypadnie jeszcze powrócić - mieszkanka) - miasto - oprawca (w obu wypadkach będzie to deweloper, co pozwala widzieć w tych powieściach echa aktualnej polityki miejskiej i wciąż narastających konfliktów między wykluczającymi się wizjami polis). U źródła tak silnego przywiązania do miasta (a właściwie własnej dzielnicy) widzieć można założenie o ścisłym związku między tożsamością jednostki a przestrzenią - zadomowienie oznacza dla bohaterek przywoływanych utworów imperatyw etyczny - konieczność wzięcia odpowiedzialności za własny dom. Jak zauważa Elżbieta Sidoruk w swojej interpretacji powieści Chutnik:

7 D. Kozicka, Sylwia Chutnik, czyli kobieta w mieście, s. 136. O połączeniu przestrzeni publicznej z estetyką, ideologią i fokalizacją w twórczościach Chutnik pisze M. Roszczynialska, Polityki/estetyki. Modele relacji z przestrzeniq publiczna we wspótczesnej prozie artystycznej i publicystyce (na wybranych przykładach), w: Nowe poetyki miejskie. Z problematyki urbanistycznej w literaturze XX i XXI wieku, red. M. Roszczynialska, K. Wądolny-Tatar, Kraków 2015.

8 E. Popik, Królowa Salwatora, s. 16. 
Wchodząc w dialog z poprzednikami, autorka Cwaniar sytuuje swoje pisanie o Warszawie „gdzieś między upodleniem a adoracją" [...] i wypracowuje własne strategie wobec miasta, które - jak twierdzi - trzeba "oswoić", by nie stać się jego ofiarą i móc w nim normalnie żyć: „Chcę oswajać, pogłaskać i przypodobać się niewielkim terenom, aby nie zostać pożartą przez metropolię z kłapiącą szczęką. Zaczynam od skali mikro, bazar, cmentarz, mała miejscowość podwarszawska. Szukam objawów swojskości w ograniczonej przestrzeni: kamienica, kilka ulic, jakiś sklep czy dancing. Potem przenoszę się do miasta równoległego. Nie tyle wymyślonego, ile nieodkrytego" $[\ldots]^{9}$.

„Między upodleniem a adoracją” uznać można za formułę analogiczną do dialektyki miłości i nienawiści, jaka cechuje stosunek powieściowych bohaterek do miasta. Wszystkie one jednak dokonują oswojenia przestrzeni, odnajdując swojskość we własnym kawałku metropolii, za który należy wziąć odpowiedzialność i podjąć walkę - w imię ochrony tożsamości, poczucia bezpieczeństwa i owej swojskości właśnie. Walka rozgrywać się przy tym będzie w przestrzeni publicznej. Bohaterki obu powieści dokonują bowiem „umysłowej reprezentacji i emocjonalno-afektywnej oceny danego wycinka środowiska, które jednostka włącza do koncepcji samej siebie i postrzega jako część samej siebie" ${ }^{10}$. W tym sensie bitwa o miasto jest bitwą o siebie samych, zgodnie z twierdzeniem Davida Harveya, klasyka społecznej myśli miejskiej, że „pytanie o to, jakiego miasta chcemy, nie może być oddzielone od pytania o to, jakimi chcemy być ludźmi, jakiego rodzaju stosunków społecznych poszukujemy, jakie relacje z przyrodą sobie cenimy, jakiego stylu życia pragniemy i jakie wartości estetyczne pielęgnujemy" ${ }^{11}$.

Przestrzeń urbanistyczna staje się w powieściach Chutnik i Popik areną ujawniania się konfliktów i ideologicznych rozgrywek. Jednak również jej ponowoczesne przemiany są przez autorki tematyzowane. Cytowany już Czepczyński dokonuje systematyzacji funkcji pełnionych przez miejską przestrzeń publiczną:

Centralny plac miasta może być utożsamiany z różnymi historycznymi pojęciami, wskazującymi na dominację określonej, historycznej funkcji centralnej czy miastotwórczej: - Agora, czyli przestrzeń politycznych dysput i manifestacji. - Piazza, pełniąca funkcję miejsca spotkań mieszkańców i przybyszy, wymiany informacji czy życia kulturalnego. - Rynek, będący tradycyjnym miej-

\footnotetext{
9 E. Sidoruk, "Okolica znana, oswojona". Warszawa w "Cwaniarach" Sylwii Chutnik, s. 136.

10 W. Łukowski, Społeczne tworzenie ojczyzn. Studium tożsamości mieszkańców Mazur, Warszawa 2002, s. 82-83.

11 D. Harvey, Bunt miast. Prawo do miasta i miejska rewolucja, przeł. A. Kowalczyk i in., Warszawa 2012, s. 22.
} 
scem wymiany handlowej, targowisko i centrum handlu, będące dla większości miast podstawowym czynnikiem lokalizacji. - Ulica, zdominowana przez funkcje transportowe, ale także węzeł i komunikacyjne centrum miasta. - Salon, pełniący przede wszystkim funkcje reprezentacyjne: miejsce, gdzie lokalne społeczności wizualizują swoje wyobrażenia i potrzeby miejskości ${ }^{12}$.

Wszystkie wymienione wyżej typy miejsc odnaleźć można w obu omawianych powieściach. Z tym, że zarówno Chutnik, jak i Popik ukazują proces przemiany tradycyjnych "centrów" i ich (po)nowoczesne, nierzadko problematyczne, inkarnacje. Szczególnie wyraźnie uwidacznia się to w figurze salonu. Tradycyjnie bywa on przecież kojarzony z miejską elitą (a więc z ośrodkami wiedzy/władzy). Wyróżnione miejsce staje się źródłem miejskiej kultury i wyrafinowanej dysputy. Tak rozumiany salon, podobnie zresztą jak wszystkie inne przywołane przez Czepczyńskiego przestrzenie, wiąże się silnie z pojęciem miejskiego centrum.

To właśnie w degradacji tradycyjnej roli centrum, jaka cechuje ponowoczesne polis, upatrywać należy przyczyny wielu przemian przestrzeni publicznej. Niewydolność miastotwórczych funkcji centrum i deficyt jego symbolicznych znaczeń (związanych z utożsamieniem go z władzą, rozumem, bezpieczeństwem i społecznym konsensusem ${ }^{13}$ ) skutkuje także głębokimi przemianami w życiu społecznym mieszkańców oraz w ich codziennych praktykach przestrzennych.

W poststrukturalistycznej literaturze zajmującej się miastem, enklawy (dzielnice) rozumiane są jako lokalne węzły międzynarodowych struktur kapitałowych i kulturowych, ukrywające się pod maską lokalności: osiedla zamknięte, dzięki marketingowej magii, stają się jednostkami sąsiedzkimi, centra handlowe stają się nowymi targowiskami, a dzielnice turystyczne oferują symulakrę autentycznych miast, które właśnie zastępują ${ }^{14}$

- tę diagnozę znaleźć można w większości opracowań poświęconych problemom nowoczesnej przestrzeni publicznej. Wobec niedomagania Centrum i jego porażki w swojej miastotwórczej i integrującej społeczność roli, zadanie to przejmują centra lokalne - dzielnicowe. A wobec przemian i kryzysów

\footnotetext{
12 M. Czepczyński, Przestrzeń publiczna jako forma reprezentacji społeczności lokalnych, s. 10.

13 Na temat tradycyjnej symboliki centrum zob. T. Sławek, Akro/nekro/polis: wyobrażenia miejskiej przestrzeni, w: Pisanie miasta. Czytanie miasta, red. A. Zeidler-Janiszewska, Poznań 1997.

14 D.R. Judd, Visitors and the Spatial Ecology of the City, w: Cities and Visitors: Regulating Cities, Markets, and City Space, red. L.M. Hoffman, S.S. Fainstein, D.R. Judd, Malden 2003, s. 23. Cyt. za: K. Nawratek, Miasto jako idea polityczna, przedmowa J. Staniszkis, Kraków 2008, s. 40.
} 
społecznego wymiaru życia miejskiego - potencjał do zmiany drzemie nie $\mathrm{w}$ magistracie, ale na peryferiach ${ }^{15}$.

Stąd staje się jasne, że dziewiętnastowieczny z ducha miejski salon wobec braku centrum - musi zostać zastąpiony formami odpowiadającymi przeobrażeniom społecznej struktury miasta. Jak pisze Aleksandra Hołubowicz o Cwaniarach:

widoczne jest zjawisko, które Rafał Drozdowski nazywa „upraktycznianiem” przestrzeni publicznej, czyli jej oddolne przystosowywanie do potrzeb lokalnych mikrowspólnot. Przykładem zaczerpniętym z powieści Chutnik może być Romek, przedstawiciel lokalnego "marginesu”, który między kamienicami uprawia zioła w swoim ogródku, do którego prawo nabył raczej poprzez zawłaszczenie przestrzeni „niczyjej" niż akt notarialny. Drozdowski ów proces upraktyczniania miejsc "niewidzialnego miasta” uznaje za wpisujący się w codzienność, a także docenia „potężny ładunek spontanicznej, oddolnej kreatywności i innowacyjności mieszkańców". Innymi przykładami podobnych procesów z Cwaniar mogą być „podwórza dostosowane do suszenia prania, a przy okazji do sąsiedzkich spotkań, ogródki działkowe służące intensywnej uprawie warzyw i owoców, fragmenty placów budowy urządzane jako namiastki pomieszczeń socjalnych". Miejsca tego typu Drozdowski określa mianem „agor" i „klubów” - czyli przestrzeni, z których wiele pełni funkcje „uwspólnotawiającą"16.

Podwórza, ogródki przejmują w powieści Chutnik nie tylko rolę salonu (miejsca wizualizacji wyobrażeń i potrzeb miejskości), ale także agory rozumianej jako przestrzeń politycznych dysput i manifestacji. To właśnie rozmowy na temat kształtu miasta i zagrożeń dla jego trwania wypełniają strony obu powieści. Jeszcze wyraźniej „upraktycznianie” przestrzeni publicznej ilustruje Popik, tworząc przestrzennym, symbolicznym i ideologicznym centrum swojej powieści dzielnicowy klub. To właśnie w jego przestrzeni nie tylko dokonują się projekty zmian w dzielnicy, rekonstruowana jest przeszłość Biskupiej Górki i werbalizują się marzenia mieszkańców (funkcja salonu), odbywają się dysputy i rozgrywają konflikty (funkcja agory), ale również jest to miejsce wyrażania emocji. Znamienna w tym kontekście jest scena organizacji zarówno wieczoru wspomnień dzielnicowych seniorów,

15 Pisze o tym również w kontekście twórczości Chutnik Magdalena Roszczynialska: „chciałam zwrócić uwagę, że «uruchomienie», kinetyzacja przestrzeni urbanistycznej we wszystkich branych przeze mnie pod uwagę tekstach łączy się z przemieszczeniem miasta w kierunku od centrum ku przedmieściom, ku sferom peryferyjnym. Chodzi także o przemieszczenie w znaczeniu ontologicznym lub epistemologicznym: o zanik centrum lub możliwości jego rozpoznania" [M. Roszczynialska, Polityki/estetyki, s. 212].

16 A. Hołubowicz, Miasto jako przestrzeń zagrożona - refleksje na podstawie powieści "Cwaniary" Sylwii Chutnik, s. 216. 
jak i warsztatów teatralnych dla kobiet. Obie te sceny to nie tylko przykłady „upraktyczniania” przestrzeni publicznej, ale również emocjonalnej spontaniczności, którą przejawiają mieszkańcy miasta w stosunku do własnej dzielnicy.

Co znamienne, $\mathrm{w}$ omawianych powieściach dzielnica jest silnie przeciwstawiona centrum miasta. To właśnie w lokalności drzemią emocje, które stają się potencjałem zmiany. Centrum przypomina skostniałe, dalekie od afektów, miejsce zarezerwowane dla władzy i biznesu. W Cwaniarach jedna $\mathrm{z}$ bohaterek, Halina, powracając na Mokotów z Bródna, „[p]rzecięła dziedziniec Zamku, omijając slalomem wycieczkę pstrykającą zdjęcia powietrzu, chmurom i temu dziwnemu zapachowi luksusowych hoteli położonych w centrum miasta” ${ }^{17}$. W całej „warszawskiej” powieści Chutnik centrum miasta pojawia się ledwie na kilku stronach. Jawi się przy tym jako przestrzeń obca dla bohaterki, zarezerwowana dla biznesu i turystów. Zostaje już kilka stron dalej skontrastowana ze swojskością dzielnicy:

Kiedy wchodzisz do miejsca znajomego, gdzie barmanka kiwa głową i bez słowa przynosi, co należy, to wiesz, że jesteś stąd. Można jeździć po świecie, czemu nie, wszak podróże kształcą, ale najważniejsze jest własne miejsce na stojaku rowerowym i własny stolik w knajpie ${ }^{18}$.

Chutnik podkreśla opozycję centrum-peryferie, jednocześnie potwierdzając diagnozy badaczy ponowoczesnego miasta o upadku idei centrum (przemienionego $\mathrm{w}$ symulakrum historycznego miasta, produkt miastopodobny przeznaczony do konsumpcji przez turystów) i powstawaniu nowych form lokalności.

W Królowej Salwatora centrum Gdańska funkcjonuje jako synonim ośrodka władzy i funduszy. Znamienne są pojawiające się w powieści opisy tej przestrzeni, jak na przykład scena rozgrywająca się w Dworze Artusa:

Podchodziły kolejno osoby, padały słowa powitania, tu wszyscy się znali. Była to elita miasta. Rozmawiali ze sobą wykładowcy uniwersyteccy, dyrektorzy ważnych instytucji, urzędnicy miejscy wysokiego szczebla. Kręcili się wśród nich dziennikarze z gazet i portali internetowych, w końcu podjechał wóz telewizyjny i operatorzy weszli do środka. [...]. Na samym środku tuż przed gośćmi w krzesłach postawiono na parkiecie dwa gdańskie fotele, czarne, o rzeźbionych poręczach i szczytach, na których umieszczono herb, trzymany przez lwy ${ }^{19}$.

\footnotetext{
17 S. Chutnik, Cwaniary, s. 45.

18 Tamże, s. 55.

19 E. Popik, Królowa Salwatora, s. 267.
} 
Centrum zamieszkane jest więc przez elitę (u Chutnik - finansową, $u$ Popik - związaną z foucaultiańską wiedzą/władzą). Ludzie centrum skontrastowani są z bohaterami, których konstruują obie pisarki, jakby zgodnie ze słowami Krzysztofa Nawratka, stwierdzającego że:

Człowiek Centrum, właśnie dlatego, że jest w Centrum, ma znacznie większy obszar możliwości, w którym może funkcjonować. Pochodzenie z Centrum - przy minimalnym wysiłku - gwarantuje bezpieczeństwo, złudzenie posiadania wpływu na swoje życie i na otaczający świat. Bycie człowiekiem Peryferii i człowiekiem Centrum to dwie całkowicie różne sytuacje egzystencjalne i społeczne ${ }^{20}$.

My (lokalni, dzielnicowi, pełni emocji, kobiecy) zostają skontrastowani wobec „nich” (centralnych, wyzbytych uczuć, męskich). Prawdziwe życie miejskie toczy się bowiem nie $\mathrm{w}$ ratuszu, ale na ulicy. Klubik miejski w Królowej Salwatora przejmuje rolę i tradycyjnego salonu, i agory. Z kolei dzielnicowe ulice zastępują niewydolną piazza i zamieniony na centra handlowe rynek. W obu powieściach lokalne, „oswojone” zakątki nie zostają sprowadzone tylko do funkcji transportowych, ale stają się miejscami spotkań mieszkańców i przybyszy, życia kulturalnego, wymiany handlowej, wymiany informacji, ale także prezentacji emocji (bójek, festynów, zbiegowisk). Tak zredefiniowana przestrzeń publiczna wymaga też odmiennego typu bohatera miejskiego. W Cwaniarach są nim dbające o porządek chuliganki, ale też:

Najlepszymi znawcami śmietnikowych skarbów są nurkowie, którzy buszują codziennie $\mathrm{w}$ kontenerach, korzystając $\mathrm{z}$ tego, że jedni są bogaci, a drudzy biedni. Że jedni nie potrzebują, a znów drugim się przyda. Reakcje łączone, łańcuchy wzajemnych zależności, podtrzymują tkankę miejską w należytym porządku ${ }^{21}$.

Inaczej konstruuje ten podział Popik. $Z$ jednej strony jej powieść można odczytać jako apel o zachowanie gdańskich tradycji dzielnicowych i oryginalnej tkanki miejskiej Biskupiej Górki. Z drugiej strony końcowe zwycięstwo mieszkańców nie jest możliwe bez pomocy „elity”. Bierni i ubodzy bohaterowie Królowej Salwatora zyskują obrońców w osobach kierowniczki dzielnicowego klubu, nauczycieli miejscowej szkoły oraz zamożnego i wpływowego darczyńcy. Wprowadza to do powieści pewną dwuznaczność, a powiele-

\footnotetext{
20 K. Nawratek, Miasto jako idea polityczna, s. 105.

21 S. Chutnik, Cwaniary, s. 94.
} 
nie społecznego schematu nie pozwala widzieć w tekście Popik manifestu „prawa do miasta”. Schematyzm ten ułatwia jednak lekturę Królowej Salwatora jako świadectwa głęboko zakorzenionych miejskich wyobrażeń przestrzenno-symbolicznych. Gdański Dwór Artusa to przecież nie tylko miejsce właściwe dla spotkań elity, skupisko atrybutów polis (wspomniane gdańskie fotele i herb z lwami), ale też miejsce oddzielone niewidoczną granicą. Scena jej przekraczania wydaje się ważna także ze względu na emocje, jakie przeżywa bohaterka - aspirująca do roli przewodniczki miejskiej Baśka:

Baśka zatrzymała się przed budynkiem Nowego Ratusza. Miała przed sobą ważne zadanie. Bała się, czy zdoła przeprowadzić swój zamiar. [...]. Podeszła do solidnych kamiennych schodów. Zwalniała kroku, dopiero teraz uświadomiła sobie, na jak szalony i śmiały ruch zamierza się poważyć. Miała w sobie wiele odwagi, co wynikało z jej poryw czego charakteru. Działania jej wystrzeliwały z podświadomości, nie przekładały się na słowa. Jeden gest, krzyk i po wszystkim [wyróż. - K.S.] ${ }^{22}$.

Przejście od peryferii do centrum (w sensie symbolicznym, nie topograficznym, gdyż Biskupia Górka jest fragmentem gdańskiej dzielnicy Śródmieście) oznacza konfrontację z przestrzenią rozumu, słowa, władzy - w przeciwieństwie do lokalności jako ostoi podświadomości, gestu i emocji. Wiąże się $\mathrm{z}$ niepewnością, strachem, a nawet wstydem (szczególnie zwraca uwagę fragment, kiedy Baśka zostaje przez zamożnych turystów wzięta za żebraczkę ze względu na swój ubogi ubiór). Jak pisze Marta Smagacz-Poziemska:

miasto postrzegane jest jako struktura społeczno-przestrzenna, która reprodukowana jest $\mathrm{w}$ toku codziennych praktyk społecznych [...], przestrzeń miasta współtworzona jest przez reprezentacje przestrzeni [...], na odtwarzanie przestrzeni i przekształcanie przestrzeni miejskiej wpływ mają również emocje czy - jak określa to Löw - struktury emotywne, zarówno wytwarzane przez praktyki społeczne, jak i kształtowane przez reprezentacje przestrzeni ${ }^{23}$.

Posługując się zacytowaną terminologią, można stwierdzić, że „struktury emotywne", które odtworzyły w swoich powieściach Chutnik i Popik, kreowane są przez społeczne stratyfikacje i wyrażane $\mathrm{w}$ podejmowanych przez ich bohaterki praktykach przestrzennych. Te zaś wpływają na kształt przestrzeni publicznej - problem jej przemian zostaje w Cwaniarach i Kró-

\footnotetext{
22 E. Popik, Królowa Salwatora, s. 302.

${ }^{23}$ M. Smagacz-Poziemska, Czy miasto jest niepotrzebne? (Nowe) przestrzenie życiowe młodych mieszkańców miasta, Warszawa 2015, s. 35-36.
} 
lowej Salwatora stematyzowany, ale też konstrukcja fabularno-przestrzenna pozwala widzieć w mieście ekran konfliktów i emocji, jakie przeżywają postaci. Są to gniew, wstyd, niezgoda na marginalizację, ale też miłość i marzenie o zmianie. Uczucia znajdują dla siebie ujście w praktykach spacjalnych podejmowych codziennie w mieście (jakby zgodnie $\mathrm{z}$ myślą Michela de Certeau, że indywidualne akty chodzenia są niezgodą wobec narzuconego systemu urbanistycznego ${ }^{24}$ ), ale ostatecznym katharsis okazuje się, co ciekawe, społeczny rytuał - $\mathrm{u}$ Popik festyn i rekonstrukcja historyczna, u Chutnik odwołująca się do mitu walczącej Warszawy akcja "partyzancka”. W obu wypadkach rytuał znajduje legitymizację w przeszłości miasta (zabytkowy zegar na budynku schroniska w Królowej Salwatora, figura kanałów w Cwaniarach), co pozwala mówić o jeszcze innej emocji silnie oddziałującej na motywacje i zachowania bohaterek. Byłaby nią nostalgia za dawnym miastem i wrażenie niewydolności współczesnej tkanki miejskiej.

Omawiane powieści są też świadectwami redefinicji klasycznej wartościującej opozycji centrum-peryferie. Metaforycznie ujmuje to poniższy fragment tekstu Popik:

Gudman pochylił się nad mapą. Leżała na politurowanym blacie stołu. Była tak duża, że brzegami niemal dotykała krawędzi. Pokazywała dzielnicę. Pagórki, na których stały domy przy krętych ulicach, narysowano w gęstszych rzędach jako równoległe półkola. Niebieska rzeka obejmująca je u podstawy, wyglądała jak wstążka, wyjęta z włosów dziewczynki i kunsztownie ułożona. [...]. Linie ulic przecinały się na samym środku pod kątem prostym. Jedna biegła $z$ dołu do góry, druga, poprzeczna, z lewej strony na prawą. Wyznaczały punkt centralny ${ }^{25}$.

We fragmencie tym pobrzmiewa i wspomniana już nostalgia za dawną świetnością miasta, i utopijne marzenie o miejscu idealnym, i - wreszcie - konstatacja relokacji Centrum, które znajduje się tam, gdzie agora, salon i ulica, czyli w oswojonej, lokalnej przestrzeni dzielnicy, „w której splatają się społeczne więzi, konstruują znaczenia, a napięcia i konflikty nabierają wymiaru kulturowego" 26 .

\footnotetext{
24 Zob. M. de Certeau, Wynaleźć codzienność. Sztuki działania, przeł. K. Thiel-Jańczuk, Kraków 2008.

25 E. Popik, Królowa Salwatora, s. 68.

26 W. Maćków, J. Zimpel, Rewitalizacja dzielnicy, w: Kulturowe studia miejskie. Wprowadzenie, red. E. Rewers, Warszawa 2014, s. 458.
} 


\section{Bibliografia}

Barbaruk Magdalena (2018), Sensy błądzenia. La Mancha i jej peryferie, Kraków-Nowy Sącz: Wydawnictwo Pasaże.

Buczyńska-Garewicz Hanna (2006), Miejsca, strony, okolice. Przyczynek do fenomenologii przestrzeni, Kraków: Universitas.

Certeau de Michel (2008), Wynaleźć codzienność. Sztuki działania, przeł. K. Thiel-Jańczuk, Kraków: Wydawnictwo Uniwersytetu Jagiellońskiego.

Chutnik Sylwia (2012), Cwaniary, Warszawa: Świat Książki.

Czepczyński Mariusz (2012), Przestrzeń publiczna jako forma reprezentacji społeczności lokalnych. Między hibernacją a animacja centrów matych miast woj. pomorskiego, "Studia KZPK", nr 144, s. 7-19.

Harvey David (2012), Bunt miast. Prawo do miasta i miejska rewolucja, przeł. A. Kowalczyk i in., Warszawa: Fundacja Nowej Kultury Bęc Zmiana.

Hołubowicz Aleksandra (2014), Miasto jako przestrzeń zagrożona - refleksje na podstawie powieści "Cwaniary” Sylwii Chutnik, "Jednak Książki. Gdańskie Czasopismo Humanistyczne", nr 1, s. 213-229.

Judd Dennis R. (2003), Visitors and the Spatial Ecology of the City, w: Cities and Visitors: Regulating Cities, Markets, and City Space, red. L.M. Hoffman, S.S. Fainstein, D.R. Judd, Malden-Oxford-Carlton: Blackwell Publishing Ltd., s. 23-38.

Kozicka Dorota (2015), Sylwia Chutnik, czyli kobieta w mieście, „Śląskie Studia Polonistyczne" 2015, nr 1, s. 131-142.

Łukowski Wojciech (2002), Społeczne tworzenie ojczyzn. Studium tożsamości mieszkańców Mazur, Warszawa: Scholar.

Maćków Weronika, Zimpel Jadwiga (2014), Rewitalizacja dzielnicy, w: Kulturowe studia miejskie. Wprowadzenie, red. E. Rewers, Warszawa: Narodowe Centrum Kultury.

Nawratek Krzysztof (2008), Miasto jako idea polityczna, przedmowa J. Staniszkis, Kraków: Korporacja Ha!art.

Popik Emma (2019), Królowa Salwatora, Gdańsk: Marpress.

Roszczynialska Magdalena (2015), Polityki/estetyki. Modele relacji z przestrzenia publicznq we wspótczesnej prozie artystycznej i publicystyce (na wybranych przykładach), w: Nowe poetyki miejskie. Z problematyki urbanistycznej w literaturze XX i XXI wieku, red. M. Roszczynialska, K. Wądolny-Tatar, Kraków: Wydawnictwo Naukowe Uniwersytetu Pedagogicznego, s. 206-227.

Sławek Tadeusz (1997), Akro/nekro/polis: wyobrażenia miejskiej przestrzeni, w: Pisanie miasta. Czytanie miasta, red. A. Zeidler-Janiszewska, Poznań: Wydawnictwo Fundacji Humaniora, s. 11-40.

Sidoruk Elżbieta (2018), "Okolica znana, oswojona”. Warszawa w "Cwaniarach" Sylwii Chutnik, „Białostockie Studia Literaturoznawcze”, nr 13, s. 133-148.

Smagacz-Poziemska Marta (2015), Czy miasto jest niepotrzebne? (Nowe) przestrzenie życiowe młodych mieszkańców miasta, Warszawa: Scholar. 


\title{
District as Affective Place: Cwaniary by Sylwia Chutnik and Królowa Salwatora by Emma Popik
}

\begin{abstract}
The article analyzes two urban novels Cwaniary by Sylwia Chutnik and Królowa Salwatora by Emma Popik. Both present the vision of city as an affective place. Their strongest similarity is in the way they project emotions upon the city and the transformations of public space which they document. The author of the article proposes to concentrate on a number of questions. These include the affective experience of urban space, polis as the space of ideological tensions, relationship between the centre and periphery, postmodern understanding of locality, and finally, the status of a district as the site of settling in, which allows one to claim "the right to the city".
\end{abstract}

Keywords: urban fiction, city studies, urban space, locality, postmodernity 